\title{
Effects of Dried Onion and Ascorbic Acid on Performance, Immune Response and Serum Blood Lipid Profiles of Growing Rabbits
}

\author{
H. S. Zeweil, M. H. Ahmed, S. M. Zahran ,Y.El-Gindy and A . Y. Al-Ghdaiwi \\ Department of Animal and Fish Production, Faculty of Agriculture (Saba Basha), \\ Alexandria University.
}

\begin{abstract}
Thirty-six growing V-line rabbits of both sexes, 5 weeks old, with initial weights of $791.7 \pm 14.1 \mathrm{~g}$ were used for the study through summer season from June to September(2104). The rabbits were randomly allocated to four treatments groups of 9 rabbits each. Each treatment was further sub-divided into 3 replicate of $r$ rabbits. Group one fed control diet free of feed additives and served as a control group. Group 2 and 3 supplemented with 400 and $800 \mathrm{mg}$ dried onion / kg diet, respectively. Group 4 received control diet, but drinking water supplemented with $200 \mathrm{mg}$ vitamin C / I water. Results showed that at 15 weeks of age the live body weight was significantly $(P$ $\leq 0.05$ ) increased by the addition of ascorbic acid and dried onion at different inclusion rate. $A$ significant decrease in feed consumption was recorded in the group received diet supplemented with $800 \mathrm{mg}$ onion / $\mathrm{kg}$ diet in comparison with the control group. Significant $(P \leq 0.05)$ improvement in feed conversion ratio was observed in dried onion or ascorbic acid groups in comparison with the control. Hematological parameters were insignificantly affected by treatments. Dried onion and ascorbic acid failed to induce any significant impact on sheep red blood cells(SRBCs) in comparison with the control group. All feed additives significantly $(P \leq 0.01)$ reduced serum total lipids, triglycerides, total cholesterol and low density lipoprotein, however, they had insignificant effect on high density lipoprotein concentration in comparison with the control group. Malondialdehyde as an indicator of lipid peroxidation was significantly decreased in all treatments, however, only the group received $400 \mathrm{mg}$ onion in their diet recorded significant $(P \leq 0.05)$ increase in total antioxidant capacity in comparison with the control group. In conclusion, rabbit dietary supplementation with ascorbic acid or dried onion could have beneficial effects on performance under summer environment without any side effects.
\end{abstract}

Key words: Rabbits, dried onion, ascorbic acid, performance, immunity and blood lipid profile

\section{INTRODUCTION}

The sub-therapeutic uses of antibiotics to enhance growth and prevent the infectious intestinal diseases have led to a problem of drug residues in final animal products and emerge of new antibiotic-resistance bacteria (Frankic et al., 2009). In Egypt, the routine use of antibiotics in animal and poultry diets have been banned in November 2006 and thus, some endeavors are made to develop new in-feed antibiotics substitutes for reducing and treating infectious diseases in rabbit and poultry industry. Attempts to use the natural materials such as herb and botanicals could be widely accepted as feed additives to improve the efficiency of feed utilization and animal productive performance (Zeweil et al., 2013). Ascorbic acid is one of the most widely studied vitamins used to alleviate heat stress in rabbits. Amakye-Anim et al. (2000) and El-Ghaffar et al. (2000) showed that, ascorbic acid has a role in lowering viral pathogenic actions and in protecting animals from heat 
stress as well as in the enhancement of the immune system of infected rabbits. Ascorbic acid is not considered a required dietary nutrient, but under certain adverse environmental conditions, the metabolic need for this vitamin may exceed the inherent biosynthetic ability of ascorbic acid (Abou-Ashour et al., 2004). However, many additives are recently added to rabbit feed or water as a way to help alleviate adverse effect during summer months and to enhance productive performance and immune response of rabbits. Onion bulbs have numerous organic sulphur compounds, flavonoids and phenolic acids with proven antibacterial, antioxidant and hypolipidemic efficacy (Melvin et al., 2009; Srinivasan et al., 2004). The results of Goodarzi et al. (2013) showed the beneficial influence of onion extract on the growth performance in meat-type broiler chickens. Vidyavati et al. (2010) suggested that the serum cholesterol was significantly decreased by dietary dehydrated onion in experimentally hypercholesterolemic rats. The aim of the present study is to determine the effects of dried onion and ascorbic acid as feed additives on growth performance, blood hematology, immune response and serum blood lipid profiles of growing rabbits through summer season from June to September.

\section{MATERIALS AND METHODS}

Thirty-six growing V-line rabbits of both sexes, 5 weeks old, with initial weights of $791.7 \pm 14.1 \mathrm{~g}$ were used for the study. The rabbits were randomly allocated to four treatments groups of 9 rabbits each. Each treatment was further sub-divided into 3 replicate of $r$ rabbits. Rabbits were housed in wire floor batteries of $45 \times 36 \times 36 \mathrm{~cm}$ and were offered diets for duration of the feeding trial until reaching 15 weeks of age. All animals were kept under similar hygienic conditions. Rabbits were housed in well ventilated block building. Fresh air circulated in the house using exhaust fans. The rabbits were kept within a cycle of $16 \mathrm{~h}$ light and $8 \mathrm{~h}$ dark. Four pelleted diets were prepared. Group one fed control diet free of feed additives and served as a control group. Group 2 and 3 supplemented with 400 and $800 \mathrm{mg}$ dried onion / $\mathrm{kg}$ diet, respectively (American garden product - New York 11783 USA). Group 4 received control diet, but drinking water supplemented with $200 \mathrm{mg}$ vitamin C /L (Fisher chemical -analytical reagent Grande). Fresh water was automatically available at all times through stainless steel nipples for each cage. The experimental diets were offered to rabbits ad libitum. The formula of basal experimental diet is presented in Table (1) that formulated to cover the requirements of rabbits according to NRC (1977).

Individual body weight and feed consumption were recorded weekly. Body weight gain and feed conversion ratio were also calculated. The incidence of dangerous diseases was largely avoided and rabbits have never been treated with any kind of systematic vaccination or medication. At the end of the feeding trial, 3 rabbits were selected from each treatment group randomly, starved of food but not water for 12 hours and slaughtered for carcass analysis. Before slaughtering, $6 \mathrm{ml}$ 
of blood sample was taken from the ear vein with a sterile syringe. $3 \mathrm{ml}$ of the blood was put into a bijon bottle containing ethylene diamine tetracetic acid (EDTA) as an

Table (1). Composition and chemical analyses of the basal experimental diet.

\begin{tabular}{lc}
\hline \multicolumn{1}{c}{ Ingredients } & $\%$ \\
\hline & \\
Yellow corn & 19.0 \\
Wheat bran & 11.0 \\
Barley & 17.2 \\
Berseem hay & 33.0 \\
Soybean meal (44\%) & 15.0 \\
Molasses & 3.0 \\
Di-calcium phosphate & 1.0 \\
L-lysine & 0.1 \\
DI-Methionine & 0.1 \\
Premix & 0.3 \\
Salt & 0.3 \\
\hline \multicolumn{1}{c}{ Total } & 100 \\
\hline Chemical analyses: & \\
Dry matter (DM), \% & 91.36 \\
Crude protein(DM), \% & 17.24 \\
Ether extract(DM), \% & 3.26 \\
Crude fiber(DM), \% & 12.58 \\
Nitrogen free extract(DM), \% & 50.47 \\
Ash(DM), \% & 7.57 \\
Organic matter (OM), \% & 92.42
\end{tabular}

${ }^{1}$ Vit+Min mixture provides per kilogram contains: Vit A 6000 IU; Vit $D_{3} 450$ IU; Vit E 40 mg; Vit $K_{3} 1$ $\mathrm{mg}$; Vit $B_{1} 1 \mathrm{mg}$; Vit $B_{2} 3 \mathrm{mg}$; Vit $B_{3} 180 \mathrm{mg}$; Vit $B_{6} 39 \mathrm{mg}$; Vit $B_{12} 2.5 \mathrm{mg}$; Pantothenic acid $10 \mathrm{mg}$; biotin $10 \mathrm{mg}$; folic acid $2.5 \mathrm{mg}$; choline chloride $1200 \mathrm{mg}$; Manganese $15 \mathrm{mg}$; Zinc $35 \mathrm{mg}$; Iron 38 $\mathrm{mg}$; Copper $5 \mathrm{mg}$; Selenium $0.1 \mathrm{mg}$; lodine $0.2 \mathrm{mg}$; Selenium $0.05 \mathrm{mg} .{ }^{2}$ Analyzed values according to AOAC (2006).

Anticoagulant for haematological assay. The remaining $3 \mathrm{ml}$ of the blood sample was put into a sterile vacutainer tube without an anticoagulant for serum biochemical analysis. The haematological assay was carried out to determine erythrocyte indices such as packed cell volume (PCV), and haemoglobin $(\mathrm{Hb})$ values. Red blood cell (RBC) counts were counted on an AO Bright line hemocytometer using a light microscope at 400X magnification after diluting blood samples 200 times with a physiological saline $(0.9 \% \mathrm{NaCl}$ solution) before counting (Natt and Herrick, 1952). White blood cell (WBC) were counted on an AO Bright line hemocytometer using a light microscopeat 100X magnification after diluting blood samples 20 times with a diluting fluid (1\% acetic acid solution with a little of Leishman's stain) before counting (Hepler, 1966). Total lipids, triglycerides, cholesterol, low density lipoprotein (LDL) and high density lipoprotein (HDL), 
concentrations in serum were estimated using commercial kits (Bio Merieux, France) accordingto the procedure outlined by the manufacturer. Three rabbits of each treatment were immunized with $0.1 \mathrm{ml}$ of a $2.5 \%$ Sheep Red Blood Cells (SRBC) via the marginal ear vein at 15 days after starting the dietary treatment supplementation, to measure Antibody titer against Sheep Red Blood Cells. The dosage of SRBC for inoculation was pre-determined by a separate trial. Antiserum to SRBC was collected 7, 14 and 21 days post challenge. One $\mathrm{ml}$ of blood was refrigerated to allow red blood cells to settle. If sedimentation was not complete, samples were centrifuged for 1 to $2 \mathrm{~min}$ at $3000 \mathrm{rpm}$ to separate serum and erythrocytes, and the supernatant was collected. Briefly, 96-well plates were first filled with $25 \mu \mathrm{l}$ of physiological saline solution in each well. Then $25 \mu \mathrm{l}$ of antiserum was pipetted into the first well in duplicates after which $25 \mu \mathrm{l}$ from the first well was pipetted into the second well, and so forth using an automatic pipette. Finally, a $0.75 \%$ of SRBC solution was added to each well. Plates were incubated at $37^{\circ} \mathrm{C}$ for 3 hours and then examined visually for agglutination Wegmann and Smithies. (1966). The agglutination titer was expressed as the $\log ^{2}$ of the reciprocal of the highest serum dilution giving complete agglutination (Nelson et al., 1995). The results were expressed as the mean \pm SEM. All data were analyzed using one way analysis of variance (ANOVA) using SPSS 11.0 statistical software (SPSS, Inc., Chicago, II, 2001). Significant differences between means were detected using new Duncan multiple range test (Duncan, 1955).

\section{RESULTS AND DISCUSSIONS}

The impact of dietary treatments on growth performance indices is presented in Table 2. At 15 weeks of age the live body weight was increased by the addition of ascorbic acid and dried onion at different inclusion rats. The obtained results and recorded observation clearly focused in group received ration supplemented with 400 and $800 \mathrm{mg}$ onion / kg diet. Results showed that diets containing 400 and $800 \mathrm{mg}$ onion / $\mathrm{kg}$ diet resulted in numerical increase in weight gain and significant $(P \leq 0.05)$ increase in daily weight gain through the experimental period from 5-15 weeks of age. Goodarzi et al.(2013) reported that dietary supplementation of $30 \mathrm{~g} / \mathrm{kg}$ onion bulb increased final body weight of broilers at $42^{\text {nd }}$ day of age compared to the other treatments $(P \leq 0.05)$ fed $15 \mathrm{mg}$ Virginiamycin / $\mathrm{kg}$ or dietary supplementation of $10 \mathrm{~g}$ onion bulb/kg diet. The above results may be explained due to their contents of sulphur components that are considered as active antimicrobial agents. Similar to our results also was obtained by Ajiet al. (2011)reported an enhancement in body weight of broilers received diets containing fresh onion bulbs as compared with birds fed basal diet. Concerning ascorbic acid, Al-Shanty (2003) showed that adding ascorbic acid (1.0 $\mathrm{g} / \mathrm{L}$ water) significantly improved averages of daily gain when compared with the control group. Selimet al. (2004) cleared that rabbits had access to extra levels of ascorbic acid beyond recommendation level achieved $(P \leq 0.01)$ better live weight gain compared to the control group. More recently, Selim et al. (2008) found that 
diet treated with 200 ppm of ascorbic acid recorded significantly ( $P \leq 0.01)$ the highest weight gain (1312 g vs. $943 \mathrm{~g}$ in control group).

A significant $(P \leq 0.05)$ decrease in feed intake in the group received diet supplemented with $800 \mathrm{mg}$ onion / kg diet in comparison with the control group through the experimental period, however, insignificant effect on feed intake was observed due to addition of $400 \mathrm{mg}$ onion or ascorbic acid. This result agrees partially with that obtained by Ibrahim et al. (2004)

Table (2). Effect of dried onion and ascorbic acid on rabbit's performance

\begin{tabular}{lcccc}
\hline \multirow{2}{*}{ Characteristics } & Control & \multicolumn{2}{c}{ Onion (mg/kg diet) } & \multirow{2}{*}{$\begin{array}{c}\text { Ascorbic } \\
\text { acid }\end{array}$} \\
\cline { 3 - 4 } & & $\mathbf{4 0 0}$ & $\mathbf{8 0 0}$ & $\mathbf{2 0 0 ~} \mathbf{~ m g / l}$ \\
\hline Initial body weight, g & $687.8 \pm 89.1$ & $665.56 \pm 100.1$ & $683.9 \pm 112.90$ & $687.8 \pm 84.6$ \\
Final body weight, g & $2373.9 \mathrm{~b} \pm 78.6$ & $2418.9 \mathrm{a} \pm 92.6$ & $2484.4 \mathrm{a} \pm 100.3$ & $2399.4 \mathrm{a} \pm 113.6$ \\
Daily weight gain, g & $22.8 \pm 1.0^{\mathrm{b}}$ & $25.1 \pm 2.0^{\mathrm{a}}$ & $25.7 \pm 2.2^{\mathrm{a}}$ & $24.5 \pm 2.0^{\mathrm{ab}}$ \\
Daily feed onsumption, & $74.68 \pm 1.11^{\mathrm{ab}}$ & $75.86 \pm 3.47^{\mathrm{a}}$ & $66.86 \pm 5.16^{\mathrm{c}}$ & $70.62 \pm 6.52^{\mathrm{bc}}$ \\
Feed conversion ratio & $3.83 \pm 0.20^{\mathrm{a}}$ & $3.54 \pm 0.30^{\mathrm{b}}$ & $3.24 \pm 0.29^{\mathrm{c}}$ & $3.58 \pm 0.36^{\mathrm{ab}}$ \\
\hline
\end{tabular}

Different letters (a-c) within a raw denote significant differences between treatments $(P \leq 0.05)$

Who reported a significant decrease in feed consumption and the largest reduction of feed consumption in broiler ducks were observed when received $3 \%$ garlic $(5.2 \%)$ and $1 \%$ onion $+3 \%$ garlic $(4.6 \%)$ but cumulative feed consumption at week $0-10^{\text {th }}$ lower than the same at $0-12^{\text {th }}$ week. Goodarzi et al. (2013) reported that birds fed $30 \mathrm{~g}$ onion $/ \mathrm{kg}$ in the diet had the highest $(P \leq 0.05)$ feed intake than the other treatments fed $15 \mathrm{mg}$ Virginiamycin/kg or dietary supplementation of $10 \mathrm{~g}$ onion bulb/kg diet. Birds fed $10 \mathrm{~g}$ onion bulb/kg diet was significantly equal to the group fed the control diet. Aji et al. (2011) reported an enhancement in average feed intake of broilers offered diets containing fresh onion bulbs in comparison with broilers fed basal diet. Sallam et al. (2005) indicated that the treatment with ascorbic acid (40 mg/kg body weight) resulted in non-significant increase in feed intake and drinking water comparing with those of control group. Moreover, Selim et al. (2004) reported that the treated with ascorbic acid (300 mg/kg diet) did not significantly affect feed intake.

In contrast, Shehata (2005) reported that ascorbic acid supplementation caused significant increase in feed intake. In addition, Yassein et al. (2008) showed that the water supplementing with ascorbic acid at $1 \mathrm{~g} / \mathrm{L}$ increased daily feed consumption when compared with those of control group of NZW rabbits does.

The observed results showing that supplementation of dried onion or ascorbic acid improve ( $P \leq 0.05)$ the feed conversion ratio in comparison with the control group. The groups fed 400 and $800 \mathrm{mg}$ onion $/ \mathrm{kg}$ showed better feed 
conversion ratio (3.54 and 3.24) vs. control group (3.83). The same results were obtained by Ibrahim et al. (2004) on broiler dusks and they attributed the improvement in feed conversion ratio to the reduction of small intestine thickness since the nutrient absorption is more efficient through thinner intestinal wall that reflected on the improvement of absorption which translated to improvement in feed conversion ratio.

Similar to our results Aji et al.(2011) reported an enhancement in feed conversion ratio of broilers offered diets containing fresh onion bulbs in comparison with broilers fed basal diet. On the other hand, El Nawawy (1991) found that feed conversion ratio was nearly identical when compared Hubbard broiler chicken control with those fed garlic, onion or garlic plus onion. Using ascorbic acid, Selim et al. (2004) reported that rabbits had access to extra levels of ascorbic acid beyond recommendation level achieved better performance in feed conversion ratio compared to the control group. In addition, Selimet al. (2008) cleared that the treated with $200 \mathrm{ppm}$ of ascorbic acid recorded significantly the best feed conversion ratio (2.68 vs. 3.68 in control group).

Results presented in Table 3 indicated that hematological parameters of the rabbits showed insignificant effect on hematocrit, RBCs, WBCs, and $\mathrm{Hb}$ of rabbits given different levels of onion or ascorbic acid in comparison with the control group. The percentage of lymphocytes, eosinophils, neutrophils and monocytes were not affected by different treatments also in comparison with the control group. The normal hematocrit indicates the absence of normocytic anemia.

The result is corroborated by the normal RBCs which further elucidated the absence of hemolytic anemia and depression of erythrogenesis. The normal hemoglobin concentration for all the experimental rabbits is probably an indication that onion or ascorbic acid at studied levels supported hemoglobin synthesis, which according to Sirosis (1995) is among other factors, primarily affected by protein intake. Njidda et al. (2006) reported that normal range of values for $\mathrm{Hb}$ indicated that the vital physiological relationship of hemoglobin with oxygen in the transport of gases (oxygen and carbon dioxide) to and from the tissues of the body has been maintained and was normal. 
J. Adv. Agric. Res. (Fac. Agric. Saba Basha)

Table (3). Effect of dried onion and ascorbic acid on hematological parameters and sheep RBCs of growing rabbits at 15 weeks of age

\begin{tabular}{|c|c|c|c|c|}
\hline \multirow{2}{*}{ Characteristics } & \multirow{2}{*}{ Control } & \multicolumn{2}{|c|}{ Onion (mg/kg diet) } & \multirow{2}{*}{$\begin{array}{c}\text { Ascorbic } \\
\text { acid } \\
200 \mathrm{mg} / \mathrm{l} \\
\end{array}$} \\
\hline & & 400 & 800 & \\
\hline $\begin{array}{l}\text { Red blood cells (RBCs) } 10^{6} \\
\text { White blood cells(WBCs) } 10^{3} \\
\text { Hemoglobin (Hb)mg/dl } \\
\text { PCV \% } \\
\text { Eosinophil \% } \\
\text { Neutrophils \% } \\
\text { Lymphocytes \% } \\
\text { Monocytes \% }\end{array}$ & $\begin{array}{c}3.57 \pm 0.11 \\
6.40 \pm 0.52^{\mathrm{ab}} \\
10.70 \pm 0.45^{\mathrm{ab}} \\
33.03 \pm 1.26 \\
3.33 \pm 0.57 \\
55.00 \pm 1.00^{\mathrm{ab}} \\
39.67 \pm 1.52 \\
4.67 \pm 0.58\end{array}$ & $\begin{array}{c}3.53 \pm 0.17 \\
7.36 \pm 0.73^{\mathrm{a}} \\
10.53 \pm 0.45^{\mathrm{b}} \\
33.30 \pm 1.47 \\
3.33 \pm 0.57 \\
52.67 \pm 2.08^{\mathrm{b}} \\
40.00 \pm 1.73 \\
4.67 \pm 0.58\end{array}$ & $\begin{array}{c}3.54 \pm 0.12 \\
5.56 \pm 1.59^{\mathrm{b}} \\
10.50 \pm 0.30^{\mathrm{b}} \\
33.97 \pm 1.18 \\
3.67 \pm 0.58 \\
55.00 \pm 1.00^{\mathrm{ab}} \\
38.67 \pm 2.08 \\
5.33 \pm 0.57\end{array}$ & $\begin{array}{c}3.73 \pm 0.10 \\
6.07 \pm 0.30^{\mathrm{ab}} \\
11.46 \pm 0.50^{\mathrm{a}} \\
32.70 \pm 5.49 \\
3.33 \pm 0.58 \\
55.33 \pm 0.58^{\mathrm{a}} \\
37.66 \pm 2.52 \\
4.67 \pm 0.57\end{array}$ \\
\hline $\begin{array}{l}\text { Sheep } \mathbf{R B C s} \text { titer } \\
7 \text { days } \\
14 \text { days } \\
21 \text { days }\end{array}$ & $\begin{array}{l}0.660 \pm 0.05 \\
0.743 \pm 0.05 \\
0.736 \pm 0.12\end{array}$ & $\begin{array}{l}0.687 \pm 0.09 \\
0.740 \pm 0.08 \\
0.770 \pm 0.00\end{array}$ & $\begin{array}{l}0.687 \pm 0.09 \\
0.770 \pm 0.00 \\
0.816 \pm 0.04\end{array}$ & $\begin{array}{l}0.660 \pm 0.05 \\
0.767 \pm 0.07 \\
0.766 \pm 0.07\end{array}$ \\
\hline
\end{tabular}

Different letters (a-c) within a raw denote significant differences between treatments $(P \leq 0.05)$

Dried onion and ascorbic acid failed to induce any significant impact on SRBCs in comparison with the control group (Table 3). Results presented by Goodarziet al. (2013) found that dietary supplementation of 10 and $30 \mathrm{~g}$ onion bulb/kg diet fiasco to induce any significant effect on antibody titers against NDV, although the weight of lymphoid organs was significantly $(P \leq 0.05)$ higher for birds fed diets supplemented with $30 \mathrm{~g} / \mathrm{kg}$ Onion. In the present trial SRBCs measured, neither positive nor negative effect was affected. Since antimicrobial agents started to be used as growth promoters, researchers (Coates et al., 1952; White hair and Thompson, 1956) working with broilers and swine respectively understood that the presence of an important health challenge in the field was essential to reveal the significant effects of these products. This was while the current trial was conducted in optimum conditions and no external challenges were impelled to the rabbits. On the other hand, Lee et al. (2014) suggested that an onion peel extract supplement at levels 4,20 , or $100 \mathrm{mg} / \mathrm{kg}$ can improve the immune status of rats by increasing the number of immune-related cells and specific cytokine levels in comparison with the control group.

Results illustrated in Table 4 indicated that all feed additives used in the present study were significantly $(P \leq 0.01)$ reduced serum total lipids, triglycerides, total cholesterol and low density lipoprotein; however, they had insignificant effect on high density lipoprotein concentration in comparison with the control group. Generally, it was observed that $800 \mathrm{mg}$ dried onion was more effective in decreasing serum total lipids, total cholesterol and low density lipoprotein, 
J. Adv. Agric. Res. (Fac. Agric. Saba Basha)

however, ascorbic acid was more effective in decreasing serum triglycerides concentration in comparison with the other experimental groups.

Table (4). Effect of dried onion and ascorbic acid on serum lipid profile at 15 weeks of age

\begin{tabular}{|c|c|c|c|c|}
\hline \multirow{2}{*}{ Characteristics } & \multirow{2}{*}{ Control } & \multicolumn{2}{|c|}{ Onion (mg/kg diet) } & \multirow{2}{*}{$\begin{array}{c}\text { Ascorbic } \\
\text { acid } \\
200 \mathrm{mg} / \mathrm{l}\end{array}$} \\
\hline & & 400 & 800 & \\
\hline Total lipids, mg/dl & $320.00 \pm 4.6^{a}$ & $310.67 \pm 12.5^{\mathrm{a}}$ & $217.00 \pm 5.3^{b}$ & $230.00 \pm 4.0^{b}$ \\
\hline Triglycerides, mg/dl & $80.87 \pm 2.4^{a}$ & $70.30 \pm 1.5^{\mathrm{b}}$ & $71.20 \pm 0.9^{b}$ & $63.97 \pm 1.4^{c}$ \\
\hline Total cholesterol, mg/dl & $112.33 \pm 1.5^{\mathrm{a}}$ & $102.40 \pm 6.6^{b}$ & $61.90 \pm 0.8^{d}$ & $70.53 \pm 1.5^{c}$ \\
\hline High density lipoprotein,mg/dl & $49.66 \pm 0.6$ & $48.00 \pm 2.6$ & $48.67 \pm 1.2$ & $49.33 \pm 1.2$ \\
\hline Low density lipoprotein, $\mathrm{mg} / \mathrm{dl}$ & $48.60 \pm 1.2^{\mathrm{a}}$ & $38.23 \pm 6.7^{b}$ & $31.1 \pm 0.8^{c}$ & $38.40 \pm 2.4^{\mathrm{b}}$ \\
\hline Total antioxidant capacity, $\mathrm{mmol} / \mathrm{l}$ & $0.90 \pm 0.10^{\mathrm{b}}$ & $1.85 \pm 0.57^{\mathrm{a}}$ & $1.20 \pm 0.26^{b}$ & $1.41 \pm 0.09^{\mathrm{ab}}$ \\
\hline Malondialdehyde, $\mathrm{nmol} / \mathrm{ml}$ & $68.90 \pm 3.18^{a}$ & $46.07 \pm 4.49^{b}$ & $49.37 \pm 5.36^{b}$ & $45.07 \pm 4.41^{\mathrm{b}}$ \\
\hline
\end{tabular}

Different letters $(\mathrm{a}-\mathrm{c})$ within a raw denote significant differences between treatments $(\mathrm{P} \leq 0.05)$

Suresh and Srinivasan (1997) found that $3 \%$ onion powder reduced blood lipids, lipid peroxides and cholesterol. Goodarzi et al. (2013) reported that broilers receiving $30 \mathrm{~g} / \mathrm{kg}$ onion had a significantly higher HDL and lower triglyceride concentrations compared to control group and dietary supplementation of $10 \mathrm{~g}$ onion bulb/kg diet. Also, An et al. (2015) stated that the concentrations of serum free cholesterol and triacylglycerol in broilers groups fed diet containing onion extract were significantly decreased compared with those of control or the group fed diet containing antibiotic $(P \leq 0.01)$.Chung et al. (2011) reported that onion peel extract supplementation to Sprague-Dawley male rats fed high fat diet significantly decreased serum level of LDL-cholesterol and increased HDL-cholesterol, while total cholesterol and triglyceride level were not affected. Hematological parameters were also not significantly affected by treatments. In contrast, Sklan et al. (1992) did not observe any effect of onion on hepatic cholesterol. The effects of onion have been ascribed to its sulfur containing principles which oxidize thiol compounds either present free or combined with a protein and NADPH which are necessary for lipid synthesis (Sebastian et al., 1979). The lipid lowering action of Smethyl cysteine sulfoxide (SMCS) isolated from Allium cepa was investigated in Sprague-Dawley rats fed on 1\% cholesterol diet (Kumari and Augusti, 2007). Administration of SMCS at a dose of $200 \mathrm{mg} / \mathrm{kg}$ body weight for 45 days ameliorated the hyperlipidemic condition. The lipid profile in serum and tissues showed that concentrations of cholesterol, triglyceride and phospholipids were significantly reduced when compared to their untreated counterparts. The total lipoprotein lipase activity in the adipose tissue was decreased with also a decrease in the free fatty acid levels in serum and tissues. The activities of the lipogenic enzymes glucose 6-phosphate dehydrogenase and malic enzyme as also of 3hydroxy-3-methyl-glutaryl-CoA reductase in the tissues remained low on treatment 
indicating that SMCS did not favor lipogenesis and cholesterogenesis in the hyperlipidemic animals. The fecal excretion of bile acids and sterols was further increased upon treatment with SCMS.

Concerning ascorbic acid, Gad Alla et al. (2002) reported that cholesterol was significantly decreased with ascorbic acid addition as compared to the control group of bucks and does Bouscat rabbits. Also, Yousef et al. (2003) found that rabbits treated with ascorbic acid $(20 \mathrm{mg} / \mathrm{kg}$ BW) showed a decrease in plasma cholesterol. However, Yousef (2004) suggested that ascorbic acid supplementation significantly decreased the level of total lipids and cholesterol. Similarly, Ibrahim (2005) found that vitamin C significantly decreased the cholesterol level by $4.7 \%$ compared to the control group. On the other hand, Salem et al. (2003) investigated the influence of ascorbic acid supplementation on some blood constituents of growing New Zealand White rabbits. They indicated that ascorbic acid supplementation did not effect on the serum cholesterol.

Malondialdehyde (MDA) as an indicator of lipid peroxidation was significantly decreased in all treatments in comparison with the control group (Table 4), while the results showed numerical increasein serum total antioxidant capacity (TAC) in the groups given $800 \mathrm{mg}$ onion or $200 \mathrm{mg}$ ascorbic acid. However, the group received $400 \mathrm{mg}$ onion in their diet recorded significant $(\mathrm{P} \leq$ $0.05)$ increase in total antioxidant capacity in comparison with the control and 800 $\mathrm{mg}$ onion fed groups. It is reported that oral administration of fresh onion juice (3 cc/daily) for 4 weeks meaningfully decreased serum MDA levels, however, it increased TAC in Wistar rats (Khaki et al., 2012). The same reduction on MDA levels is demonstrated in male rats treated with onion (Ige and Akhigbe, 2012). The study of Prakash et al.(2007) showed that onion (Allium cepa) is a rich source of polyphenols with promising antioxidant and free radical scavenging potentials and has the ability to provide protection against DNA damage caused by reactive oxygen and reactive nitrogen species. Ogunlade et al. (2012) reported that under stress of alcohol administration in rabbits the results showed a statistically significant decrease in superoxide dismutase (SOD), catalse (CAT) and glutathione peroxidase (GPx) activity in liver compared to control animals, however, treatment with combined alcohol and Allium cepa (AC) significantly increased the liver SOD, CAT and GPx activity compared to animals that received alcohol alone. The authors also showed that alcohol significantly elevated the liver lipid peroxides expressed as MDA by about five folds as compared to the control value, however, co-administration of alcohol and Allium cepa (AC) exhibited a notable reduction in the liver MDA level compared to alcohol alone treated rabbits. Abdel-Salam et al. (2014) reported that the essential oils of red onion had the highest phenolic contents and antioxidant activity in contrast to garlic essential oils. In addition, Peluso et al. (2015) demonstrated that the onion peel ethanol extract have a strong antioxidant activity with quercetin and polyphenol proposed to be the major 
J. Adv. Agric. Res. (Fac. Agric. Saba Basha)

components responsible for this effect suggesting the possibility that an onion peel supplement could improve the immune status.

In conclusion, rabbit dietary supplementation with ascorbic acid or dried onion could have beneficial effects on performance under summer environment without any side effects.

\section{REFERENCES}

Abdel-Salam, A. F., M. S. Elaby and J. B. Ali (2014). Antimicrobial and antioxidant activities of red onion, garlic and leek in sausage. African Journal of Microbiology Research, 8: 2574-2582.

Abou-Ashour, A. M. H., S. A. A. Abd El-Rahman, G. A. Zanaty, A. A. Essa and M. K. Abou El-Naga (2004). Effect of dietary ascorbic acid supplementation on the performance of laying hens. Egypt. Poult. Sci., 24: 401-416.

Aji, S. B., K. Ignatius, Y. Ado and A. Abdulkarim (2011). Feeding Onion (Allium cepa) and Garlic (Allium sativum) on some performance characteristics of broiler chickens. Research Journal of Poultry Sciences, 4: 22-27.

Al-Shanti, H. A. (2003). Using vitamin C and sodium bicarbonate to alleviate the effect of heat-stress on rabbit performance. Egypt poult .Sci. , 23(1): 115127.

Amakye-Anim, J. T. L., P. Y. Lin Hestree, D. Thiagrajan, B. A. Watkins and C. C. Wc (2000). Ascorbic acid supplementation improved antibody response to infectious bursal disease vaccination in chickens. Poult. Sci., 79: 680-688.

An, B. K., J. Y. Kim, S. T. Oh, C. W. Kang,1 S. Cho, and S. K. Kim (2015). Effects of Onion Extracts on Growth Performance, Carcass Characteristics and Blood Profiles of White Mini Broilers. Asian-Australas J Anim Sci., 28(2): 247-251.

AOAC, Association of Official Analytical Chemists. (2006). Official Method of Analysis. $18^{\text {th }}$ Edition. Association of Analytical Chemists, Gaithersburg, MD, USA.

Chung, H. K., M. Shin, Y. Cha and K. Lee (2011). Effect of onion peel extracts on blood lipid profile and blood coagulation in high fat fed SD rats. Korea J. Food and Nutr. , 24 (3): 442-450.

Coates, M. E., M. K. Davies S. K. and Kon (1952). The ef- fect of antibiotics on the intestine of the chick. British Journal of Nutrition, 9: 110-119.

Duncan, D. B. (1955). Multiple range and F., test Biometric. 11:42.

El-Ghaffar, S. K. A., M. Aly, F. A. Moustafa and A. Z. Mahmoud (2000). Pathological studies on the rabbit viral hemorrhagic disease (RVHD) with special reference to the use of vitamin A, E and C as prophylaxis. AssiutVet. Med. J., 43 (85): 251-274.

El-Nawawy, G.H. (1991). Some of non conventional ingredients in broiler ration. M. Sc. Thesis, Ainm. Prod. Dep. Fac,. Agric., Ain-Shams Univ.

Frankic, T., M. Voljc, J. Salobir and V. Rezar (2009). Use of herbs and spices and their extracts in animal nutrition. ActaAgricSlovenica., 94:95-102. 
Gad-Alla S. A., A. M. Metwally, Mervet M. Arafa and M. A. Abowarda (2002). The effect of vitamin $\mathrm{C}$ and $\mathrm{E}$ supplementation and blood constituents and reproductive performance in buck and doe Bouscat rabbits. $3^{\text {rd }}$ Sci.con. on Rabbit Production in hot climates, 8-110ct: 705-714.

Goodarzi, M, M. Landy and S. Nanekarani (2013). Effect of onion (Allium cepa L.) as an antibiotic growth promoter substitution on performance, immune responses and serum biochemical parameters in broiler chicks. Health., 5:1210-1215.

Hepler, O. E. (1966). Manual of Clinical Laboratory Methods. Thomas Spring Field. Illinois.

Ibrahim, A.I., A. E. Talib and F. M. Fathi (2004). Effect of onion and/or garlic as feed additives on growth per- formance and immunity in broiler muscovy ducks. First Scientific Conference of Faculty of Veterinary Medicine, Benhar, 1-4 September 2004.

Ibrahim, Sh. A. M. (2005). Effect of some different sources of vitamin C on performance of New Zealand growing rabbit in hot climate. Egypt. poult. Sci., 25(III): 845-861.

Ige, S. F. and R. E. Akhigbe (2012). The role of Allium cepaon aluminum-induced reproductive dysfunction in experimental male rat models. $J$ Hum ReprodSci, 5:200-205.

Khaki. A., A. Farnam, A. DavatgarBadie and H. Nikniaz (2012). Treatment effects of onion (Allium cepa) and ginger (Zingiberofficinale) on sexual behavior of rat after inducing an antiepileptic drug (lamotrigine). Balkan Med J, 29: 236-242.

Kummari, K. and K. T. Augusti (2007). Lipid lowering effect of S-methyl cysteine sulfoxide from Allium cepa Linn in high cholesterol diet fed rats. J. Ethnopharmacol .,109 (3): 367-371.

Lee, H. A., S. J. Han, S. Hong, D. W. Kim, G. W. Oh and O. Kim (2014). Onion peel water extracts enhance immune status in forced swimming rat model. Lab. Anim. Res., 30(4): 161-168.

Melvin ,. M., J. Jayochitra and M. Vijayapriaya (2009). Antimicrobial activity of some common spices against certain human pathogens. J Med plants R ., 3:1134-1136

National,. Research Council (N.R.C) (1977). Nutrient Requirements of Domestic Animals USA National Academy of Science. Washington, D. C.

Natt, M. P. and C. A. Herrick (1952). A new blood diluent for counting erythrocytes and leucocytes of the chicken. Poultry Science, 31: 735-738.

Nelson, N.A., N. Lakshmanan and S. J. Lamont (1995). Sheep red blood cell and Brucella abortus antibody responses in chickens selected for multitraitimmunocompetence. Poultry Sci., 74:1603-1609.

Njidda, A. A., J. U. Igwebuike and C. E. Isidahomen (2006).Haematological Parameters and carcass characteristics of weaning rabbits fed grade levels of molasses.Global Journal of Agric. Sci., 5(7): 167-172.

Ogunlade, B., L.C. Saalu, O.S. Ogunmodede, G.G. Akunna, O.A. Adeeyo and G.O. Ajayi, (2012). The salutary role of Allium cepa extract on the liver 
histology liver oxidative status and live marker enzymes of rabbits submitted to alcohol -induced toxicity.Am.j.Biochem .mol.Biol2(2) 67-81.

Peluso, I., C. Miglio, G. Morabito, F. Ioannone and M. Serafini (2015). Flavonoids and immune function in human: a systematic review. Crit Rev Food SciNutr, 55(3): 383-395.

Prakash, D., B. N. Singh and G. Upadhyay (2007). Antioxidant and free radical scavenging activities of phenols from onion (Allium cepa). Food Chem., 102: 1389-1393.

Salem, F. A., M. R. El-Mahdy and N. M. El-Medany (2003). influence of ascorbic acid supplementation on productive performance, digestion coefficients, some blood constituents and carcass traits of growing New Zealand White rabbits. Egyptian Journal of Rabbits Science, 13(1): 37-48.

Sallam, S. M. A., M. E. A. Nasser, M. S. H. Yousef, A. M. Elmorsy, S. A. S. Mahmoud and M. I. Yousef (2005). Influence of aluminum chloride and ascorbic acid on performance, digestibility, caecal microbial activity and biochemical parameters of rabbits. Res. J. Agric. and Biological Sci., 1 (1): 10-16.

Sebastian, K., N. Zacharias and B. Philip (1979). The hypolipidemic effect of onion (Allium cepa Linn) in suc- rose fed rabbits. Indian Journal of Physiology and Phar- macology, 23: 27-30.

Selim, A. D., A. Z. Soliman and A. M. Abd El-Khalek (2004). Effect of drinking water temperatures and some dietary feed Additives on performance of heat stressed rabbits. 8th WId. Rabbit Congress, Puebla, Mexico, 984: 990.

Selim, N. A., A. M. Abdel-Khalek, S. A. Nada and S. A. El-Medany (2008). Response of growing rabbits to dietary antioxidant vitamins $\mathrm{E}$ and C. 1. Effect on performance. Proc. of the 9th World Rabbit Congress, Verona, Italy, 803-808.

Shehata, S. A. (2005). Nitrate detoxification of drinking water by ascorbic acid in growing rabbits. Wld. Rabbit Sci., 13: $93-106$.

Sirosis, M. (1995). Veterinary clinical laboratory procedure. Mosby year book, Inc. St. Louis, Missouri, USA.

Sklan, D., Y. N. Bernera and H. D. Rabinowitch (1992). The effect of dietary onion and garlic on hepatic lipid concentrations and activity of antioxidative enzymes in chicks. The Journal of Nutritional Biochemistry, 3: 322- 325.

SPSS Statistical Packages for th e Social Sciences, (2001). Statiatical software for windows version 11.0 Microsoft. SPSS ${ }^{\circledR}$, Chicago, IL, USA.

Srinivasan, K., K. Sambaiah and N. Chandrasekhara (2004). Spices as beneficial hypolipidemic food adjuncts: A review. Food Rev Int., 20:187220.

Suresh, B. P. and K. Srinivasan (1997). Influence of dietary capaicin and onion on the metabolic abnormalities associated with streptozotocin induced diabetes mellitus. Molecular and Cellular Biochemistry., 175: 49-57.

Vidyavati, H. G., H. Manjunatha, J. Hemavathy and K. Srinivasan (2010). Hypolipidemic and antioxidant efficacy of dehydrated onion in experimental rats. J Food Sci Technol., 47:55-60. 
Wegmann, T.G. and O. Smithies (1966). A simple hemagglutination system requiring small amount of red cells and antibodies. Transfusion, 6: 67-73.

Whitehair, C. K. and C. M. Thompson (1956). Observations in raising "diseasefree" swine. Journal of the American Veterinary Medical Association, 128: 94-98.

Yassein, S. A., K. Gh. M. Mahmoud, N. Maghraby O. H. Ezzo (2008). Hot climate effects and their amelioration on some productive and reproductive traits in rabbit does. World Rabbit Sci.,16: 173-181.

Yousef, M. I. (2004). Aluminium-induced changes in hemato-biochemical parameters, lipid peroxidation and enzyme activities of male rabbits: Protective role of ascorbic acid. Toxicology, (199): 47-57.

Yousef, M. I., M. H. Salem, K. I. Kamel, , G. A. Hassan and F. D. El-Nouty (2003). Influence of ascorbic acid supplementation on the hematological and clinical biochemistry parameters of male rabbits exposed to aflatoxin $\mathrm{B}_{1}$. J. Environ. Sci. Health., 38 (2): 193-209.

Zeweil, H. S., M. Mahmoud, Y. Eid, M. Abd El-Rahman and M. El-Saied (2013). Effect of supplementation of some extract of photochemical on the productive performance and carcass traits for Gimmizah chickens strain. $16^{\text {th }}$ European Symposium Poultry Nutrition 26-29 August 2013, Potsdam, Germany.

$$
\text { الملخص العربي }
$$

تأثير البصل المجفف والأسكوربيك أسبد علي الأداء والمناعة ودهون الام

في الأرانب النامية

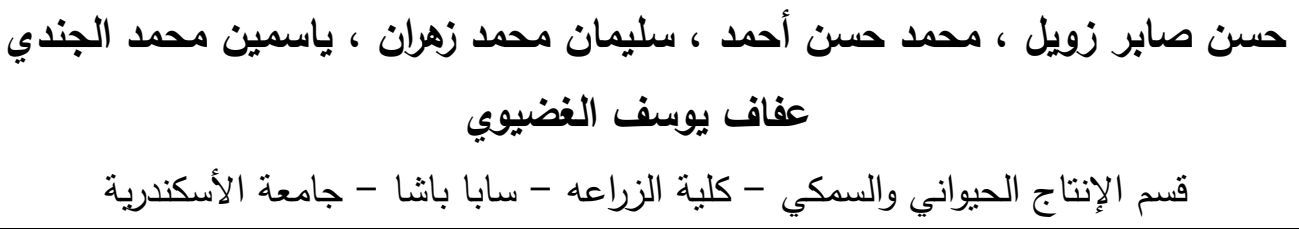

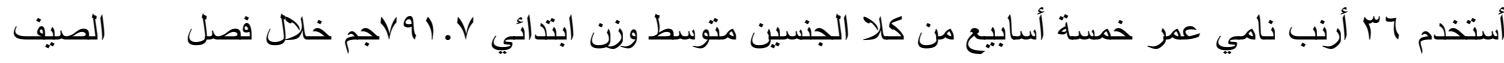

$$
\begin{aligned}
& \text { في الفترة من يونيو - سبتمبر • } \\
& \text { تم توزيع الأرانب عشوائياً علي أربع معاملات بكل معاملة تسعة أرانب ، وكل معاملة تم توزيعها علي ثلاث }
\end{aligned}
$$

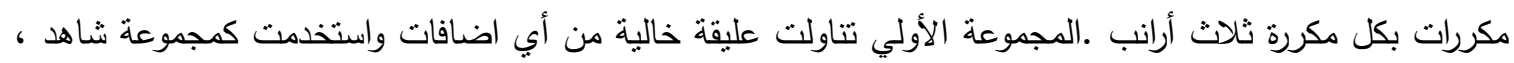

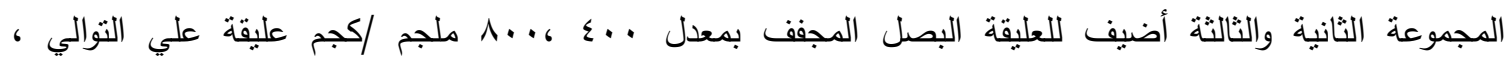

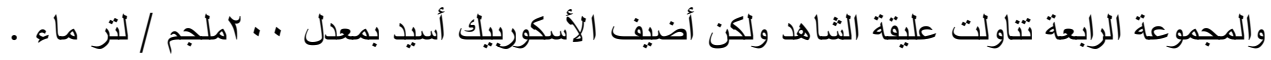


أوضحت النتائج : انه عند عمر 10 أسبوع توجد زيادة معنوية في وزن الجسم نتيجة لأضافة البصل المجف بمستويات

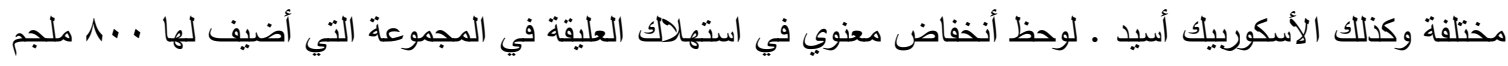
/ كجم عليقة مقارنة بمجموعة الثناهد تلاحظ تحسن معنوي في الكفاءة التحويلية في جميع المعاملات التجريبية مقارنة

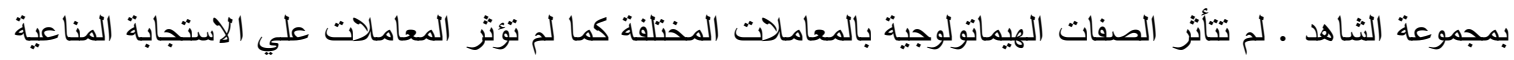

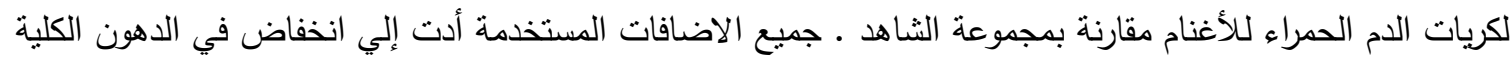

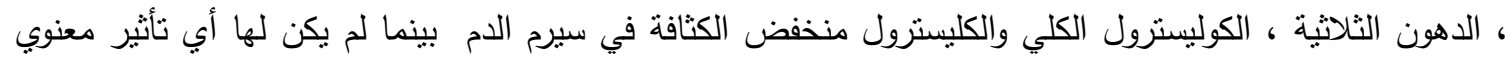

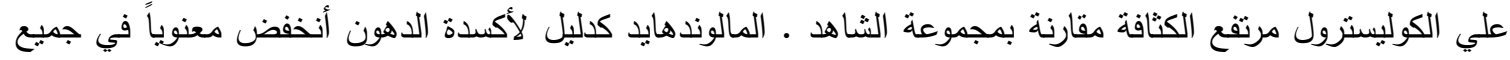

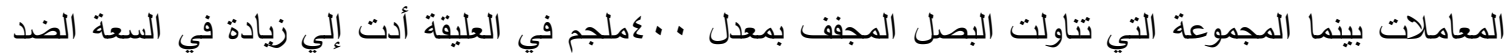

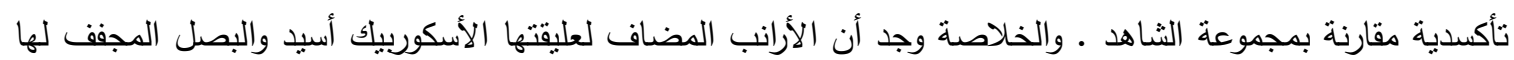
تأثثر مفيد علي أداء الأرانب خلال فصل الصيف بدون أبي تأثيرات جانبية . 